\title{
Matériaux et terres cuites architecturales : méthodes et critères de datation. Les programmes collectifs.
}

\section{Christian Sapin}

\section{(2) OpenEdition \\ 1 Journals}

Édition électronique

URL : https://journals.openedition.org/cem/340

DOI : $10.4000 /$ cem.340

ISSN : 1954-3093

Éditeur

Centre d'études médiévales Saint-Germain d'Auxerre

Édition imprimée

Date de publication : 15 août 2006

ISSN : 1623-5770

Référence électronique

Christian Sapin, «Matériaux et terres cuites architecturales : méthodes et critères de datation. Les programmes collectifs. », Bulletin du centre d'études médiévales d'Auxerre | BUCEMA [En ligne], 10 | 2006, mis en ligne le 13 octobre 2006, consulté le 22 septembre 2022. URL : http://journals.openedition.org/ cem/340; DOI : https://doi.org/10.4000/cem.340

Ce document a été généré automatiquement le 22 septembre 2022.

\section{(c) (i) (2) (2)}

Creative Commons - Attribution - Pas d'Utilisation Commerciale - Partage dans les Mêmes Conditions 4.0 International - CC BY-NC-SA 4.0

https://creativecommons.org/licenses/by-nc-sa/4.0/ 


\title{
Matériaux et terres cuites architecturales : méthodes et critères de datation. Les programmes collectifs.
}

\author{
Christian Sapin
}

1 Les deux programmes collectifs ${ }^{1}$ dont sont parties prenantes plusieurs membres $d u$ CEM se sont poursuivis en 2005-2006 :

2 Le Projet collectif de recherche Matériaux et critères de datation autour de l'an mil (PCR Ministère de la Culture) s'est réuni à trois reprises avec une quinzaine de chercheurs en 2005 à Nevers, Poitiers et Châteaudun afin de poursuivre ses travaux de comparaison des méthodes d'analyses et de datation du bâti. Ce fut l'occasion d'échanger plus spécialement autour de trois thèmes : les techniques de mise en œuvre et d'appareils, les mortiers et les enduits de recouvrement, et les sols. À la suite de la prochaine année, une synthèse des travaux en vue de publication sera envisagée.

3 Le Groupement de recherche européen (CNRS) consacré aux Terres cuites architecturales et nouvelles méthodes de datation créé en 2005, poursuit ses travaux. Ceux-ci prolongent à partir des TCA les questions soulevées par le PCR sur les matériaux en cherchant à croiser, avec les analyses ${ }^{14} \mathrm{C}$ des charbons dans les mortiers, deux méthodes de datation: thermoluminescence et archéomagnétisme. Les résultats auront des conséquences à terme sur bon nombre de recherches menées par le Centre d'études médiévales et par les archéologues du bâti en général sur les constructions. Les travaux de la campagne 2005 ont porté sur la Normandie avec des campagnes de prélèvements couplant thermoluminescence et archéomagnétisme sur les sites du Mont Saint-Michel, de Vieux-Pont-en-Auge et Ouilly-le-Vicomte; sur la région Pays-de-la-Loire à SaintMartin d'Angers, Mayenne et à Saint-Philibert de Grandlieu qui avait fait l'objet de premières recherches du CEM en 1997-1999. Il est encore trop tôt pour conclure, au moment de la publication de ce bulletin, mais les premiers résultats semblent confirmer dans plusieurs cas l'absence de réutilisation de briques antiques et des 
créations pouvant, en au moins trois exemples, se situer au $\mathrm{x}^{\mathrm{e}}$ siècle. Vérifications, calculs et précisions sont en cours ainsi que d'autres campagnes de prélèvements.

NOTES

1. Bulletin du Centre d'études médiévales d'Auxerre, Études \& travaux, CEM 9 (2004-2005), p. 189-192. 